\title{
Reviews
}

\section{Justin Kolb}

\section{The Satyr's Navel}

Joseph Campana \& Scott Maisano, eds. Renaissance Posthumanism. New York: Fordham University Press, 2016. 335 pages. $\$ 125.00$ hb; $\$ 35.00$ pb; $\$ 23.99$ Kindle.

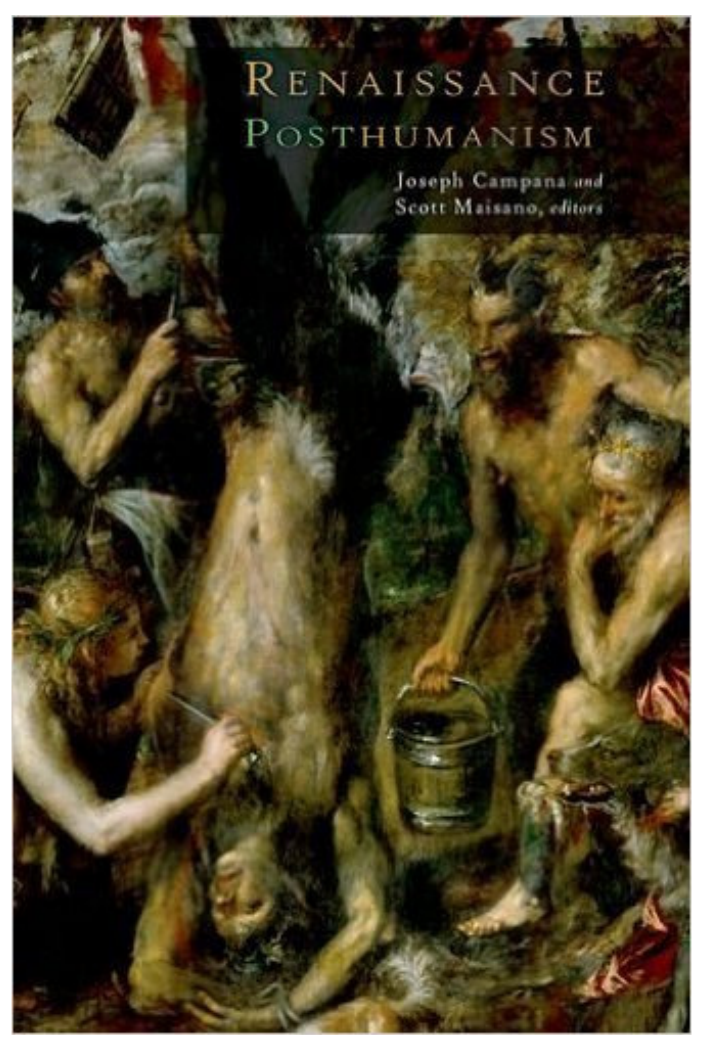

The new essay collection Renaissance Posthumanism, edited by Joseph Campana and Scott Maisano, finds its center, in true humanist fashion, at the navel of a body, artfully displayed by a master painter. But unlike Leonardo Da Vinci's "Vitruvian Man," the central figure in Titian's Flaying of Marsyas (1570-75) is not a confident, self-contained body displaying its perfections, but instead hangs upside down and abject, its legs crossed and arms dangling limp, closely crowded by torturers and onlookers. It is not a man, but a satyr, with hooves, shaggy legs, and pointed ears, a man-animal in extremis. The figure is Marsyas, the syrinx-playing satyr who, in Ovid's Metamorphoses, challenged Apollo to a musical contest, and paid for his defeat by having his skin 
painfully sliced off by the capricious god. Just below his head, one of Titian's signature dogs laps up Marsyas' blood.

In his essay on this late, possibly unfinished work, Stephen J. Campbell reads Flaying of Marsyas as an inversion of the Renaissance humanism that historians and art theorists have extracted from works like the "Vitruvian man." Inverting the image around the fulcrum of the umbilicus, Campbell uses the painting to describe a different sort of early modern humanism. Instead of offering man as the measure of all things, Titian's painting presents a body at once human and animal, not displayed in isolation, but crowded by other human, plant, animal, hybrid, and divine figures, as its skin, the membrane that separates it from the world, is peeled away.

The face of Titian's Marsyas is strangely placid, far removed from the agonized expressions found in other works on the subject. In this face, Campbell sees "not the Marsyas in Ovid who screams 'why are you stripping me from myself?'” but instead "a Marsyas who accepts an annihilation of boundaried personhood ... a dream of shattering, of the undoing/unfolding of the figure in its boundaries, of continuum of the body with matter, attained through an impossibly 'nonviolent violence,' as it was dreamed of in Dante's invocation of Apollo and Marsyas"' (91).

This dream of "undoing," of taking the imagined autonomous, distinct, superior human being and stripping him of his pretensions, of leveling the great chain of being and flaying the Vitruvian man, animates many of the essays in Renaissance Posthumanism. Grounded in an emerging canon of "posthuman" early modern primary texts Edward Topsell's A History of the Four-Footed Beasts (1607), Conrad Gessner's Historiae Animalium (1558), Giovanni Battista Gelli's La Circe (1549) - and favored theoretical interlocutors - Donna Haraway, N. Katherine Hayles, Bruno Latour, Cary Wolfe Renaissance Posthumanism arrives as animals, plants, minerals, machines, puppets, homunculi, and other sorts of nonhuman life are proliferating in early modern literary studies. Early modern animal studies alone has produced important recent titles like Laurie Shannon's The Accomodated Animal: Cosmopolity in Shakespearean Locales; Andreas Höfele's Stage, Stake, and Scaffold: Humans and Animals in Shakespeare's Theatre; and Bruce Boehrer's Animal Characters: Nonhuman Beings in Early Modern Literature. Renaissance Posthumanism is an entry in this increasingly crowded field.

The collection is admirably direct in arguing for their conception of Renaissance posthumanism. Cary Wolfe's 2010 book What is Posthumanism? is a recurring foil for the editors and several of the contributors. Kenneth Gouwens draws some precise lines in his essay "What Posthumanism Isn't: On Humanism and Human Exceptionalism in the 
Renaissance," Gouwens argues that "the scholarly community owes a debt of gratitude to Cary Wolfe for defining and deploying the term [posthumanism] with exemplary precision," but faults Wolfe for "negligible attention" to the Renaissance, which does not even appear in the book's index, or to unmentioned humanists like Petrarch, Pico della Mirandola, Erasmus, or Montaigne (38). In defining "humanism," Wolfe quotes at length from Wikipedia, thus creating a "wildly misleading" (39) picture of Renaissance humanist thought. Gouwens, as well as Campana and Maisano in their introduction, work to correct this caricature of humanism, arguing that "While many Renaissance intellectuals at time celebrated the dignity of humankind and appealed to the authority of reason," these positions "were not universally accepted tenets, and indeed were explicitly contravened in works by some of the key thinkers who have been appropriated as poster boys for anthropological optimism" (39). Rejecting Foucault's Renaissance episteme, the contributors to this volume emphasize continuity rather than rupture, and the inescapable entanglement of the human with the nonhumans all around it, even in the works of great humanist artists and writers.

These essays share a concern with vulnerability. The posthuman figures here tend to be objects rather than subjects, acted upon rather than acting, and several of the chapters argue implicitly for a surrender of human fantasies of autonomy and for passivity toward the myriad forces of the natural world. Campbell's Marsyas is one example, Vin Nardizzi's idiosyncratic praise of unlively "Wooden Actors on the English Renaissance Stage," taking on the qualities of the "Wooden O" (201) around them, is another. Erica Fudge's "Farmyard Choreographies in Early Modern England" draws on Haraway's "joint dance of being" and "oxymoron of disciplined spontaneity" (146) between humans and dogs to attempt, not always convincingly, to re-imagine early modern husbandry as a collaborative "ontological choreography" (147).

Julian Yates' sprawling "Oves et Singularium: A Multispecies Impression" examines sheep in their various forms in early modern ecology and culture: as animal, parchment, garment, and metaphor. Drawing on Wolfe and on Haraway's work on "companion species," Yates uses peasant rebel Jack Cade's brief sympathy for the "innocent lamb ... made parchment" (4.2.72) in Henry VI, Part II as the departure point for an examination of the many entanglements of humans and sheep, and how, via the pastoral metaphors of Christianity, the "sheepy metaphors" of shepherd, flock, and herd "provided a set of formal or equipmental resources for all aspects of life, and, on occasion, they were subject to playful or troubling inversions, transpositions, as in the likes of Jack's utopian projects" (181). Far from a commodity for human disposal, sheep

Humanimalia: a journal of human/animal interface studies

Volume 8, Number 1 (Spring 2017) 
are woven into human identity itself, providing the materials for defining human beings and the many ways in which they are herded and fleeced.

Human collaboration with the inhuman, conscious or not, recurs again and again in these essays. It's rarely explicitly stated, but nature is often presented here as essentially cooperative, harmonious. If human beings put aside their dominance, they will find a rich and rewarding relationship with the inhuman. These pieces tend to elide the violence and exploitation found in so many human-animal relationships, most of which are something other than cohabitation with Haraway-style companion animals. Fudge's cattle may be pulling plows before Bacon and Descartes (regular villains in early modern posthumanism) turned them into thoughtless instruments, but they were worked until they died nonetheless. Sheep may structure human life, but they get skinned and eaten anyway. In moving away from modern anthropocentrism, one can overcorrect, and start seeing pre-modern practices as kinder or more just than the evidence warrants.

Holly Dugan's "A Natural History of Ravishment" is a welcome corrective to this tendency. Dugan begins with an anecdote from the wonderfully weird English prose romance Life of Alexander, in which the conqueror and his men encounter a giant "wildman [...] covered with rough hair, with a head and voice like a swine" (121). Unsure whether the creature is man or beast, Alexander devises a test: his men "take a young damsel, strip her, and set her before the creature" (121), which becomes inflamed with lust, and sweeps her up. The damsel is recovered with some difficulty, the wildman is burned at the stake, and Alexander moves on to further adventures. Dugan uses this ambiguous encounter - is the wildman's lust a sign of his humanity or animality? - to examine the shifting boundaries between the human and animal in the Alexander romances, and the centrality of "ravishment" to drawing those boundaries. Dugan crafts a vision of nature that doesn't skirt problems of violence and domination, as many of the other essays do: "in a violent world filled with a stunning array of nonhuman actors, human women's bodies are rendered desirable - and vulnerable - to a wide variety of animals, transcending what we might term 'species boundaries.' In such tales, sexual violence emerges as a trope to define humanity" (121). Shifting focus from Alexander and his knights to the "mutual abjection" (121) of damsel and wildman, Dugan decenters a naïve model of the human while avoiding utopian fantasies of cooperation. Human beings should step down from their pedestal, but violence and exploitation will remain. 
Where Campbell sees acquiescence, even joy, in Marsyas' calm endurance of the "annihilation of boundaried personhood" (91), Dugan's feminist reading reminds us that there is nothing necessarily liberating about such annihilation:

This logic helped gird Renaissance interpretations of medieval literary tropes of ravishment as "natural" history; and it raises questions - at least for me - about our metaphors of desire that animate some posthuman theories, theories that call for an embrace of a widened nature of actants and a more-than-human world. The damsel and the beast, both abject in medieval and Renaissance accounts of this tale, remind us that such an embrace has not always been volitional. (138)

Dugan raises a question that the new posthumanisms should take on: what should a posthuman life be? Is there a livable point between the isolated Vitruvian man and abject Marsyas? Can one open to the world and still keep one's skin? Spinning in circles around the axis of the navel, where should we rest?

Humanimalia: a journal of human/animal interface studies

Volume 8, Number 1 (Spring 2017) 